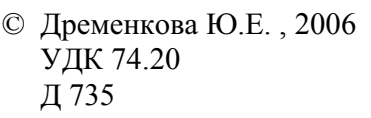

ГИГИЕНИЧЕСКИЕ ОСОБЕННОСТИ ОРГАНИЗАЦИИ УЧЕБНОГО ПРОЦЕССА В ОБЩЕОБРАЗОВАТЕЛЬНЫХ УЧРЕЖДЕНИЯХ ГУМАНИТАРНОГО ПРОФИЛЯ

\author{
Ю.Е. Дременкова
}

Территориальное управление Федеральной службы по надзору в сфере защиты прав потребителей и благополучия человека по Тульской области

В работе рассмотрены особенностей организации учеб̈ного процесса в средних школах гуманитарного профиля с разными формами учебного процесса. Дана гигиеническая характеристика учебной нагрузки, проведены исследования по субъективной оценке сложности предметов школьниками и изучение связи между сложностью предметов и учебной активностью детей.

Продолжающееся реформирование системы образования приводит к многообразию видов образовательных учреждений, широкому внедрению различных педагогических инноваций, которые в отдельных случаях ухудшают условия и режим обучения и отрицательно влияют на организм учащихся $[5,9,10]$. Увеличился поток информации, углубились программы, сократилась продолжительность рабочей недели, но увеличилась продолжительность рабочего дня. Все это приводит к увеличению учебной нагрузки, деформации режима дня, переутомлению школьников, развитию функциональных расстройств и заболеваний и, следовательно, ухудшению качества жизни $[8,13]$.

Необходимость коррекции программ и методических подходов к обучению в соответствии с анатомофизиологическими возможностями и особенностями развития детей обусловлена результатами исследований $[2,7,11]$, а так же отсутствием регламентирующих документов по их гигиенической экспертизе [6, 12].

При этом для оценки рациональности расписания и учебной нагрузки используется рекомендованная санитар- ными правилами шкала трудности предметов И.Г.Сивкова, разработанная в 1975 году, когда обучение проводилось по единым государственным программам. Данная шкала едина для всего периода обучения, как в основной, так и в старшей школе, для всех учреждений независимо от формы организации учебного процесса и не учитывает различные объемы и сложности предметов $[1,3,4]$.

\section{Материалы и методы}

Работа проводилась на базе 3 образовательных учреждений с углубленным изучением предметов гуманитарного профиля (лицей искусств № 3; гимназия №3 (школа Л.Н. Толстого); билингвистическая гимназия № 30) г. Тулы и 1 общеобразовательной школы (муниципальное образовательное учреждение «Средняя общеобразовательная школа № 25»). Исследуемые образовательные учреждения с углубленным изучением предметов гуманитарного профиля имеют отличия в программах обучения, условиях приема, организации учебного процесса, проектной вместимости и количестве учащихся. Так в гимназию № 3 принимают детей по тер- 
риториальному признаку, без предварительных экзаменов; прием в лицей искусств № 3, начиная с 5-го класса, проводится на конкурсной основе; прием в школу-гимназию № 30 проводится только на конкурсной основе.

Гигиеническая экспертиза расписания учебных занятий учащихся проводилась по рекомендуемой методике с учетом степени трудности предметов по В.И. Агаркову (1986) и И.Г. Сивкову (1975). В исследовании были использованы следующие методы: коллективные хронометражные исследования 5-ых классов, по которым так же оценивалась гигиеническая рациональность уроков и соответствие рекомендованной программе.

Учитывая, что исследуемые образовательные учреждения имели различные профили гуманитарного образования (литературный, лингвистический, искусство) и поскольку успешность обучения зависит от того, насколько трудным каждый гимназист или лицеист считает отдельный предмет для себя, исследовалась субъективная оценка трудности предметов, в виде экспертного определения самими учащимися относительной тяжести учебных дисциплин [4]. Респондентами стали 566 учащихся 5-классов указанных образовательных учреждений.

\section{Результаты и их обсуждение}

Установлено, суммарная недельная учебная нагрузка учащихся обеих гимназий и общеобразовательной школы практически не превышала нормируемых значений (в отдельных классах второй ступени обучения - 1 час). Тогда как в лицее во вторых, четвертых, десятых и одиннадцатых классов количество уроков в неделю превышало максимально допустимое значение на 1-4 чаca.

В связи с этим у учащихся вторых классов лицея № 3 на фоне организации обучения по 5-тидневной неделе выявлен самый высокий статистически достоверный показатель дневной учебной нагрузки по сравнению с другими исследуемыми учреждениями (таблица 1).

Таблица 1

Ежедневная учебная нагрузка учащихся 1-11 классов (в баллах)

\begin{tabular}{|l|c|c|c|c|}
\hline \multicolumn{1}{|c|}{ Классы } & Гимназия №30 & Лицей №3 & Гимназия №3 & Школа №25 \\
\hline Первые & $27,5 \pm 0,76$ & $26,8 \pm 0,68$ & $27,47 \pm 0,62$ & $26,87 \pm 0,62$ \\
\hline Вторые & $30,0 \pm 1,48$ & $33,4 \pm 0,74^{*}$ & $29,33 \pm 1,59$ & $28,8 \pm 0,62$ \\
\hline Третьи & $30,67 \pm 2,59$ & $28,83 \pm 1,99$ & $29,33 \pm 3,24$ & $28,73 \pm 1,62$ \\
\hline Четвертые & - & $30,17 \pm 4,22$ & $29,33 \pm 2,78$ & $29,6 \pm 3,01$ \\
\hline Пятые & $39,33 \pm 1,76$ & $35,08 \pm 1,12^{*}$ & $36,77 \pm 1,18^{*}$ & $40,8 \pm 1,04$ \\
\hline Шестые & $40,17 \pm 1,76$ & $36,23 \pm 0,86^{*}$ & $37,46 \pm 1,39^{*}$ & $41,6 \pm 1,45$ \\
\hline Седьмые & $41,83 \pm 1,76$ & $39,77 \pm 1,04^{*}$ & $41,1 \pm 1,93$ & $45,75 \pm 1,42$ \\
\hline Восьмые & $49,83 \pm 2,41$ & $41,53 \pm 1,32^{*}$ & $43,5 \pm 1,71^{*}$ & $51,07 \pm 1,59$ \\
\hline Девятые & $50,67 \pm 1,57^{*}$ & $42,31 \pm 0,93$ & $44,5 \pm 1,19$ & $41,89 \pm 2,07$ \\
\hline Десятые & $48,33 \pm 2,41$ & $48,42 \pm 1,34$ & $44,75 \pm 1,23$ & $46,44 \pm 2,99$ \\
\hline Одиннадцатые & $49,67 \pm 2,49$ & $48,58 \pm 1,93$ & $46,56 \pm 1,47$ & $47,58 \pm 2,19$ \\
\hline
\end{tabular}

При сравнительном анализе организации обучения в исследуемых учреждениях установлено, что в гимназиях и лицее обучение всех классов средней ступени (5-9 классы) осуществлялось в течение 6 дней, тогда как, в школе № 
25, с пятого по восьмой класс, обучение проводилась по пятидневной учебной неделе, что значительно повышало ежедневную учебную нагрузку учащихся. В пятых, шестых, восьмых классах общеобразовательной школы ежедневная учебная нагрузка была выше (разница статистически достоверна), чем у сверстников лицея искусств и гимназии Л.Н.Толстого. У семиклассников, обучающихся в школе №25, учебная нагрузка так же в течение дня была выше, чем у лицеистов. Достоверная разница учебной нагрузки в общеобразовательной школе и билингвистической гимназии выявлена лишь у девятиклассников, а в других возрастных группах была примерно одинакова.

Исследованиями установлено, что при составлении расписаний на день, неделю и полугодие динамика работоспособности школьников не учитывалась, за исключением только начальных классов общеобразовательной школы.

С целью выявления связи между сложностью предметов и учебной активностью школьников (хронометражные исследования) в образовательных учреждениях разного типа, нами был проведен анализ, результаты которого представлены в таблице 2.

Таблица 2

Коэффициенты корреляции между учебной активностью школьников и степенью сложностью уроков

\begin{tabular}{|l|c|c|c|c|c|c|c|}
\hline \multicolumn{2}{|c|}{ Тип учебного заведения } & 1-й урок & 2-й урок & 3-й урок & 4-й урок & 5-й урок & Общий \\
\hline \multicolumn{2}{|l|}{ Гимназия № 30 } & 0,75 & 0,74 & 0,90 & 0,43 & 0,43 & 0,60 \\
\hline \multicolumn{2}{|l|}{ Гимназия №3 } & 0,20 & $-0,23$ & $-0,42$ & 0,35 & 0,54 & 0,03 \\
\hline \multirow{2}{*}{ Лицей №3 } & хореогр. & 0,96 & 0,61 & 0,52 & 0,79 & $-0,94$ & 0,50 \\
\cline { 2 - 8 } & общеэст. & 0,74 & 0,58 & 0,73 & 0,45 & 0,83 & 0,53 \\
\hline \multicolumn{2}{|l|}{ Школа № 25 } & 0,87 & 0,89 & 0,96 & 0,74 & 0,75 & 0,72 \\
\hline
\end{tabular}

Выявлена сильная корреляционная связь между сложностью уроков и учебной активностью школьников общеобразовательной школы № 25 и корреляционная связь средней силы между изучаемыми показателями в билингвистической гимназии и лицее искусств. По-видимому, наличие корреляционной связи между учебной активностью и степенью сложности предметов определяется влиянием сложности изучаемой дисциплины на формирование мотивации к ее изучение у школьников. То есть увеличение сложности предмета является дополнительным стимулом к повышению дисциплины и внимания на уроке.

При этом наибольшая сила связи между изучаемыми показателями выявлена в гимназии № 30 и школе № 25 к третьему уроку (т.е. на пике работоспособности). В дальнейшем, к четвертому и пятому уроку отмечалось снижение величины связи, что можно объяснить уменьшением мотивации к обучению с ростом утомления в течение учебного дня. Причем вышеописанное явление было более выражено в гимназии №30, которая характеризуется более выраженной учебной нагрузкой.

Отсутствие связи между изучаемыми показателями в гимназии № 3 свидетельствует о низкой мотивации учащихся к обучению, которая скорее всего обусловлена особенностями учебной программы этого образовательного учреждения, насыщенной философскими взглядами Л.Н.Толстого, по видимому, не достаточно понятными и интересными для пятиклассников. 
Российский медико-биологический вестник имени академика И.П.Павлова, №1, 2006 г.

При сравнительном анализе сложности предметов в образовательных учреждениях различного вида выявлено, что математика для пятиклассников ли- цея, гимназии Л.Н.Толстого и общеобразовательной школы была более трудна, чем для сверстников в билингвистической гимназии (таблица 3 ).

Таблица 3

Трудность основных предметов у пятиклассников образовательных учреждений с различными профилями обучения (в усл.ед.)

\begin{tabular}{|l|c|c|c|c|}
\hline Наименование предмета & Гимназия № 30 & Лицей № 3 & Гимназия № 3 & Школа №25 \\
\hline Математика & 6,11 & 7,20 & 7,08 & 7,12 \\
\hline Иностранный язык & 6,51 & 6,79 & 6,62 & 7,48 \\
\hline Второй ин. язык & 6,10 & - & - & - \\
\hline Русский язык & 3,59 & 7,39 & 6,22 & 6,80 \\
\hline Литература & 3,16 & 4,52 & 2,71 & 4,52 \\
\hline История & 5,14 & 3,95 & 5,37 & 5,14 \\
\hline Естествознание & 3,98 & 3,76 & 6,32 & 5,92 \\
\hline Краеведение & - & - & - & 6,35 \\
\hline ОБЖ & - & 3,26 & 3,19 & - \\
\hline
\end{tabular}

Субъективная оценка трудности русского языка в пятых классах гимназии № 30 более чем в 1,5 раза была ниже, чем в других исследуемых учреждениях. При этом, в лицее данный предмет вызывал наибольшее затруднение в изучении. Не смотря на то, что в гимназии № 30 проводилось обучение по двум иностранным языкам (основной французский, и второй - английский язык), оценка трудности данных предметов была ниже, чем в других исследуемых учреждениях. Субъективная оценка трудности основных предметов в общеобразовательной школе имела высокие значения, что, вероятно связано с более подготовленным контингентом учащихся гимназий и лицеев, сформированных в результате конкурсного отбора.

При оценке ранговых мест трудности предметов в билингвистической гимназии и общеобразовательной школе наиболее трудным был иностранный язык, в гимназии Л.Н.Толстого, большую сложность вызывала математика, а у лицеистов - русский язык, тогда как, в общеобразовательной школе русскому языку было отведено третье ранговое место, в гимназии № 3 - четвертое, а в билингвистической гимназии - пятое. И если литература в лицее занимала четвертое ранговое место, то пятиклассниками в остальных исследуемых учреждениях - была отнесена к седьмому рангу. Различия в ранговых оценках были выявлены так же по истории и естествознанию.

\section{Выводы}

1. Организации учебного процесса по пятидневной учебной неделе в средних классах общеобразовательной школы ведет к резкому увеличению дневной учебной нагрузки.

2. Программами обучения, должны предусматривать набор учебных дисциплин вариативной части интересных учащимся, что способствует формированию положительной мотивации к их изучению, а, следовательно, и успехи в учебе.

3. В результате проведенных исследований был выявлен ряд сущест- 
венных отличий, как среди учреждений с различными формами обучения, так и используемого для оценки учебного процесса и рекомендуемого распределения «градаций» учебных предметов по их трудности, что подтверждает необходимость обновления созданных ранее шкал (таблиц) трудности.

\section{ЛИТЕРАТУРА}

1. Александрова И.Э., Степанова М.И. // ЗНиСО. - 2003. - № 9.- С.21-25

2. Александрова И.Э. //Гигиеническая наука и практика на рубеже XXI века.: материалы 9 Всерос. съезда гиг. и сан. врачей.-М., 2001.-Т.2.- С.275- 277.

3. Гребняк Н.П., Вербаховская Е.В. // Г-С. - 1999.-№ 3.- С.40-42.

4. Гребняк Н.П., Машинистов В.В. // Г-С. 1993.- № 6.-С.36-37.

5. Кучма В.Р. Дефицит внимания с гиперактивностью у детей России. - Распространенность, факторы риска и профилактика/В.Р.Кучма, А.Г.Платонова. M., 1997.- 200c.

6. Кучма В.Р. Современные проблемы разработки документов, регламентирующих санитарно-эпидемиологичес- кую безопасность детей и подростков// Г-С.-2004.- № 2.-С.3-6

7. Кучма В.Р. Руководство по гигиене и охране здоровья школьников/В.Р. Кучма, Г.Н. Сердюковская, А.К. Демин. М., 2000.- 151c.

8. Макарова В.И. [и др.] // Российский педиатр. журнал- 2000.- № 3.- С.60-62

9. Соловьева С.Ю. Гигиеническая оценка новых форм организации учебного процесса в старших классах общеобразовательных учреждений: автореф. дис...канд. мед. наук/ С.Ю. Соловьева. - Ростов н/ Д, 1998.- 22 с.

10. Состояние здоровья учащихся при изучении информатики в физикоматематической школе/ В.Р. Кучма [и др.]// Гигиена и санитария. - 1998.№2.- C. 27- 29.

11. Сухарева Л.М. [и др.] // Г.-С.-2004.- № 5.-c. $80-82$

12. Мониторинг функциональных возможностей организма школьников. Храмцов П.И., Шешенева Г.И. //Г-С.- 2003.-№ 5.C.56-58.

13. Чурьянова М.И.// Здравоохранение Рос. Федерации. - 1994.-№4.- С.25-28.

\title{
THE PECULIARITIES OF THE ORGANISATION OF THE TEACHING PROCESS IN EDUCATIONAL INSTITUTIONS PROVIDING GENERAL EDUCATION OF HUMANIST PROFILE
}

\author{
Yu.E. Dremenkova
}

In the article organization characteristics of educational process at specialized humanitarian schools with different types of the educational process are described. There is hygienic assessment of the educational load, investigations of subjective evaluation of the subject complexity by schoolchildren and research of connection between the complexity of the subjects and children's educational activity. 